\title{
Interpretacje
}




\title{
Zbigniew Władysław Solski
}

\section{Muzyka Ariela i muzyka Kalibana w Burzy Williama Szekspira}

\author{
Pamięci Profesora Jana Mozrzymasa \\ - założyciela Studium Generale przy Uniwersytecie Wroctawskim
}

ABSTRACT. Solski Zbigniew Władysław, Muzyka Ariela i muzyka Kalibana w "Burzy" Williama Szekspira [Ariel's and Caliban's music in William Shakespeare's The Tempest]. "Przestrzenie Teorii” 10. Poznań 2008, Adam Mickiewicz University Press, pp. 171-195. ISBN 978-83-2321946-0. ISSN 1644-6763.

Jan Kott wrote that in Tempest there is Ariel's music and Caliban's music and that there have not been a performance of The Tempest in which there would be no distinction between the two musics. Differentiation of various musics is not only a theatrical trick which serves greater dynamics the reception of the play, but it touches deeper and structural meanings. Opposition between Caliban's music and Ariel's music de facto reveals a clash of a civilisational character.

For the culture of Italy rooted in the antiquity and in the "Dionysian" by its primordial character of Ariel's culture the world of symbolism of Caliban's mother is both distant and alien. Like the witch Sycorax in the role of the queen of the island did not find common grounds with Ariel, neither can her son communicate with Prospero. Between Ariel's music and that of Caliban there is some fissure which makes it difficult to produce the state of mutual balance. On the one hand, harmony, however, unstable can be found in the relations between Prospero and Ariel. Their mutual harmony could be explained by the capability of their cultures to take up cooperation with division of the roles and with a peculiar specialisation. Prospero's "Appolinian", which is manifested in the indirect visual accounts found its complement Ariel's Dionysian culture, which was expressed directly in the recreation, in the musical symbol of the will. Thus, they were not in opposition to each other as elements of contradiction, but rather as two antithetic ways of its removal. While retaining their style, the music of Prospero and that of Ariel found unity in a common source: "the music of spheres". Was Caliban's inability to enter a dialogue with representatives of other cultures caused by the character of his defiant anti-music? Or just the opposite, the reason is hidden in the dark past, in some hurt the memory of which makes the intercivilisational exchange and cooperation difficult?

„Istnieje w Burzy muzyka Ariela i muzyka Kalibana - pisze Kott. I nie ma przedstawienia Burzy bez wyraźnego odróżnienia tych dwóch muzyk"1. Rozróżnienie odmiennych muzyk nie jest tylko teatralnym chwytem służącym zdynamizowaniu odbioru sztuki, lecz dotyka znaczeń głębszych. Burza jest najbardziej „muzyczną” sztuką w dorobku Szekspira; Kott $w$ jej strukturze szuka podobieństw do fugi, a Frye najbliższą

1 J. Kott, Pałeczka Prospera, w: Szekspir wspótczesny, Kraków 1990, s. 223. 
dla niej analogię znajduje w Zaczarowanym flecie Mozarta ${ }^{2}$. Pytanie o charakter szekspirowskiej muzyki nie znajdzie jednej odpowiedzi.

Każda kolejna lektura Burzy wskazuje na sens wspólny, o charakterze medialnym, który wyłania się z ,artystycznej gry”. Traktując dzieło Szekspira jako „punkt tożsamości ponownego rozpoznania i zrozumienia”, musimy się zgodzić z Gadamerem, że „tego rodzaju tożsamość wiąże się $\mathrm{z}$ wariacjami i różnicami"3. Nieunikniona staje się próba zastosowania "metody integralnej”, jak pisze Tomaszewski, łączącej w polifoniczny splot odmienne tropy interpretacyjne ${ }^{4}$. Sięgając po tekst Burzy, jednocześnie odwołujemy się do różnych doświadczeń inscenizacyjnych i lektur transformujących szekspirowskie motywy. Interpretacja dramatu związana jest, powiada Ratajczakowa, z „aktem kreacji artystycznej, która wieńczy dopiero zrozumienie utworu, jego przeżycie osobiste oraz ujęcie intelektualne" ${ }^{5}$. Porównując, włączamy się w dialog, w którym uobecnia się teraźniejszość z jej sprzecznościami. Sens historii ujawnia się między odrębnymi strukturami, które są transcendentalne wobec siebie nawzajem ${ }^{6}$. Dla nas są to trzy rozpoznawalne perspektywy: (1) schylkowego renesansu, posługującego się (za średniowiecznym modelem świata) pojęciami musica mundana, musica humana i musica instrumentalis, (2) krytycznej wobec przeszłości nowożytności, która odrzuciła wszelkie „nienaukowe pitagoreizmy” oraz (3) ponowoczesności, odkrywającej wraz $\mathrm{z}$ historią, że fascynacje muzyką sfer były przejawem genialnej intuicji, która wyczuwała głęboki sens liczb i figur, ujawniony przez symetrie fizyczne i teorię reprezentacji grup dopiero w XX wieku? ${ }^{7}$.

W tekście Szekspira odnajdujemy ślady procesów, których znaczenie staje się zrozumiałe dopiero w wyniku zmiany historycznej perspektywy; sens dzieła przekracza horyzont rozumienia obecny w każdej poznawczej relacji ${ }^{8}$. Burza swą niezwykłą formę zawdzięcza nierównomierności rozwoju europejskiej kultury na przełomie XVI i XVII wieku. „Kultura jako

2 N. Frye, Postowie, w: W. Shakespeare, Burza, przel. S. Barańczak, Kraków 1999 , s. 144.

3 H.-G. Gadamer, Aktualność piękna, przeł. K. Krzemieniowa, Warszawa 1993, s. 35 .

4 M. Tomaszewski, Interpretacja integralna dzieła muzycznego. Rekonesans, Kraków 2000, s. 33 i n.

5 D. Ratajczak, Teatr jako interpretator dzieła literackiego, w: Zagadnienia literaturoznawczej interpretacji, red. J. Sławiński, J. Swięch, Wrocław 1979, s. 233.

${ }^{6}$ Ph. Ariès, Czas historii, przeł. B. Szwarcman-Czarnota, Gdańsk 1996, s. 256.

7 J. Mozrzymas, A. Wolański, Harmonia sfer niebieskich i muzyka abstrakcyjnych symetrii, Wrocław 1993, s. 10.

${ }^{8}$ F. Chmielowski, Hermeneutyczny wymiar podstawowych pytań estetyki, w: Estetyki filozoficzne XX wieku, red. K. Wilkoszewska, Kraków 2000, s. 96. 
złożona całość składa się z warstw o różnym tempie rozwoju - pisze Łotman - eksplozje w jednych warstwach mogą współistnieć ze stopniowym rozwojem w innych"9. Najbardziej radykalne zmiany zaszły wówczas w muzyce: „w żadnym innym okresie historii - powiada Pociej - nie ma tak ostrego kontrastu i tak wyrazistego zetknięcia się dwóch koncepcji muzyki"; muzyka polifoniczna ustępuje nowej - ekspresyjno-monodycznej ${ }^{10}$. Ta nowa muzyka, charakteryzująca się dynamizacją, poruszeniem i nieznaną wcześniej silną emocjonalnością, podporządkowana jest „ukrytym założeniom o prymacie i wiodącej, naczelnej roli melodii”. Wzmacnia się autonomiczna wartość dzieła. Odtąd harmonia napięć estetycznych między elementami i ich wzajemna hierarchia "wyzwalana" jest każdorazowo w indywidualnym akcie twórczym. Tymczasem wcześniej kompozytor działał w ramach uniwersalnej i niezmiennej koncepcji, w której nadrzędne prawa współgrania i hierarchii elementów nie były samodzielnie ustanawiane, lecz raczej odkrywane i z pokorą realizowane. Muzyka utraciła wtedy swój dotychczasowy wymiar transcendentny, stając się „rzeczą ludzką"11. Dokonało się więc w niej to, co parę stuleci później filozofia w autorefleksji sprecyzuje: „człowiek sam wkracza na scenę - spostrzega Ricoeur - ustanawia się jako scena, na której odtąd będzie się pojawial”. Konsekwencją tej postawy stanie się „roszczenie do panowania nad bytem jako całością"12. Obie koncepcje muzyki, „polifoniczna” i „monodyczno-akompaniamentowa”, znalazły harmonijne połączenie w twórczości Monteverdiego, który mistrzowsko władal obydwiema „praktykami”. Taką samą wszechstronność znajdujemy w dziele Szekspira, który z równą łatwością rozwija polifoniczne wątki z dziesiątkami powtórzeń i lustrzanych odbić, jak z konsekwencją podporządkowuje całość dramatu „naczelnej melodii” Prospera.

Nowa muzyka i tworzone przez nią sztuki widowiskowe i operowe potrzebowały odmiennej przestrzeni. Historycznie strukturą najlepszą w swoim rodzaju, najbardziej kompletną i funkcjonalną okazał się, jak pokazał czas, barokowy teatr włoski stworzony na przełomie XVI i XVII wieku13. "Maska” z IV aktu Burzy potrzebowala tego nieznanego elżbietańskiej scenie „pudła iluzji”. Szekspir był świadomy, że w jego teatrze

9 J. Łotman, Kultura i eksplozja, przeł. B. Żyłko, Warszawa 1998, s. 41.

${ }^{10}$ B. Pociej, Swiadomość kompozytorska i poetyka muzyczna" (próba ujęcia historycznego), w: Poetyka muzyczna. Autorefleksja kompozytorska, red. E. Mizerska-Golonek, L. Polony, „Zeszyty Naukowe Akademii Muzycznej w Krakowie” 1983, nr 6, s. 26.

11 Tamże, s. 28.

12 P. Ricoe ur, Heidegger i problem podmiotu, przel. E. Bieńkowska, w: Egzystencja i hermeneutyka. Rozprawy o metodzie, wyb., oprac. i wstęp S. Cichowicz, Warszawa 1985, s. 78.

13 D. Ratajczak, Przestrzeń $w$ dramacie $i$ dramat $w$ przestrzeni teatru, Poznań 1985, s. 12. 
słowa i umowności „maska” może być jedynie mydlaną bańką, która przez małą chwilę zdoła widza utrzymać w pozorach realności. Autor zdeterminowany tym, co może zrobić w ramach sceny, którą dysponował, każe Prosperowi przerwać widowisko, powtarza zresztą ten sam dramaturgiczny chwyt we wcześniejszej scenie $\mathrm{z}$ harpią w akcie III.

Muzyka, skupiona na opanowywaniu nowej formy, zachowała jeszcze przez jakiś czas swoją dawną filozofię i wierność wcześniejszej tematyce. Nie od razu dostrzeżono związek między efektami odkryć nauk przyrodniczych i potrzebą gruntownej rewizji dotychczasowych poglądów na świat. Muzykę nadal traktowano jako przede wszystkim wiedzę teoretyczną, spokrewnioną $z$ matematyką, która podejmowała kwestie zasadniczych praw istnienia bytów $\mathrm{w}$ ich złożoności i relacjach części do całości. Balet komiczny królowej czy intermedia do Pellegriny mogły nawet wytworzyć złudne przeświadczenie, że tematyka muzyki sfer na stałe zagości na scenach operowych. W Burzy magia Prospera działała i działać tylko mogła w obrębie Modelu Wszechświata stworzonym w antyku i ugruntowanym w średniowieczu14. Rodzaj sztuki, jaką Prospero uprawiał, bliski był muzyce teoretycznej, najwyżej cenionej w intelektualistycznej koncepcji muzyki tamtych czasów. Relacje między nim a duchami, wykonawcami jego muzyki, ułożone były tak jak między musici a cantores. Wraz z zakwestionowaniem i odrzuceniem średniowiecznego modelu również dramat Szekspira stracił źródło swego znaczenia i siły. Paradoksalnie dopiero niedawne osiągnięcia fizyki odrodziły potrzebę budowania uniwersalistycznych koncepcji. Wyzwanie to podjęła również współczesna muzyka, czego świadectwo znajdujemy w refleksji Stockhausena:

\section{Boże, Ty jesteś calością \\ Galaktyki są Twymi członkami [...] \\ A my jesteśmy Twoimi atomami \\ Wypełnij nas Twym światlem ${ }^{15}$}

Szekspirowskie tytuły niekiedy wskazują na „tonację”, w której sztuka została napisana ${ }^{16}$. Zdarza się, że są to bardzo precyzyjne uwagi, jak w Wieczorze Trzech Króli lub co chcecie (The Twelfth Night), gdzie autor odwołuje się do konkretnej daty - w tamtym przypadku - Trzech Króli 6 stycznia; dwunastej nocy, licząc od Wigilii. Podobnym „kamertonem” regulującym nastrój widzów jest tytuł Sen nocy letniej (A Midsummer

14 C.S. Lew is, Odrzucony obraz, przel. W. Ostrowski, Warszawa 1986, s. 21.

${ }^{15} \mathrm{~K}$. Stockhausen, Drei Gebete, Texte III, cyt. za: K. Szw ajgier, Karlheinz Stockhausen: droga do muzycznej nadświadomości, w: Poetyka muzyczna. Autorefleksja kompozytorska, s. 222.

16 A.A. Smirnow, O sztuce Szekspira, przel. W. Dłuski, w: Szkice szekspirowskie, wyb. W. Chwalewik, Warszawa 1983, s. 400-401. 
Night's Dream) - a dokładniej - świętojańskiej. Tak też jest z Zimowq opowieściq, chociaż w tym przypadku wskazówka jest bardziej ogólna, odnosząca się nie do dnia, lecz do pory roku. W Straconych zachodach mitości dopiero w końcowej scenie widzowi daje się klucz do zrozumienia kapryśnych nastrojów tej komedii. Są to dwie pieśni: wiosny i zimy. Armado podkreślając, że słowa pierwszej brzmią twardo po wiosennej pieśni Apollona, rozstrzyga: „Idźmy. Tam wasza droga, a tu nasza”17. Z młodością współgra nastrój wiosny, nie dając się pogodzić z zimą i starością. Autor stale posługuje się metaforą ludzkiego życia zamykającego się jak rok - w jednym cyklu przemian. Pora roku, miesiąc, dzień wskazują na sytuację egzystencjalną postaci.

Burza, choć wykazuje pokrewieństwo ze wcześniejszymi przykładami, wymaga odrębnego potraktowania. Etymologia tytułu, The Tempest, ujawnia podwójne znaczenie: tempestes po łacinie to "burza" i "czas”. U Szekspira „epoka nieraz mieści się w godzinę"18, w tym dramacie cały rok, ze zmiennością swoich barw i tonów, zostaje wtłoczony $w$ jeden dzień. Nie obserwujemy tu prostego zastąpienia cyklu rocznego dziennym czy tylko nałożenia obu symbolik na siebie, lecz z olbrzymią kondensacją zdarzeń i presją czasu. Znając siły swej magii, ale też i jej ograniczenia, Prospero przedstawia córce własne położenie:

$$
\begin{aligned}
& \text {...stoję } \\
& \text { W zenicie wpływu sprzyjającej gwiazdy } \\
& \text { I jeśli chwili tej nie wykorzystam, } \\
& \text { Czeka mnie odtąd tylko schylek szans }{ }^{19} \text {. }
\end{aligned}
$$

Jego życie dobiega końca, jest tego w pełni świadomy. Przeżywa głęboki „kryzys", w pierwotnym znaczeniu tego greckiego słowa, a więc przymusu sądzenia i działania w sytuacji, gdy czas nagli. Stawką jest przyszły, pomyślny los jedynej córki, wiele rozstrzygnięć przyjmuje więc faktycznie ostateczny charakter. Właściwością skończoności człowieka jest to, że wszelkie własne sytuacje uznaje za najważniejsze i traktuje poważniej niż wszystko, co zdarzyło się do tej pory, że sam siebie stawia w centrum oceny wydarzeń. Szekspir, narzucając widzowi punkt widzenia właśnie tej postaci, posłużył się „praktyką ekspresyjno-monodyczną”. Równocześnie działania Prospera i jego późniejsze odejście przez wpisanie ich w rytm polifonicznej muzyki sfer nabierają wymiaru kosmicznego. Stykamy się więc z czasem szczególnym, czasem $\mathrm{z}$ końca dziejów.

W chrześcijaństwie panowało przekonanie, że Bóg skróci czas, zanim nastąpi koniec świata. Podczas reformacji ponaddziejowe skrócenie cza-

\footnotetext{
${ }^{17}$ Stracone zachody mitości, V. 2, L. Ulrich.

18 Zimowa opowieść, IV, 1, S. Barańczak.

${ }^{19}$ Burza, I, 1, S.B.
} 
su stopniowo przekształciło się w przyspieszenie samych dziejów ${ }^{20}$. Szekspir obrał ten sam kierunek. Skrupulatnie odmierzając godziny akcji Burzy, nie skraca czasu. Kolejne sceny rozgrywa również w coraz szybszym tempie, tempie przekraczającym ludzką percepcję. Trudno je zmierzyć krokiem, tętnem serca czy najkrótszą sylabą. Duch, Ariel, wykonawca planów Prospera, chwali się swemu panu: ,jestem twej myśli nieodłącznym echem"21, „wrócę, nim twój puls zdoła uderzyć” 22 . Zawrotne tempo, choć stale obecne w tle, nie przekłada się wprost na szybkość działania ludzi. Obserwujemy zjawisko rozwarstwienia tempa, wiążące się z coraz bardziej złożonym przeżywaniem czasu ${ }^{23}$. Prospero, nie mogąc dorównać zbyt szybkiemu tempu, raz po raz spóźnia się, wypada $z$ biegu zdarzeń. Traci panowanie nad realizacją dokładnie opracowanego planu. Zapomina o spisku Kalibana i przerywa występ aktorów w „masce”. Jego wzburzenie i napięcie narastają. Dostrzega to nawet Ferdynand. „Pierwszy raz go widzę w stanie tak gwałtownego gniewu" - zauważa też Miranda ${ }^{24}$. Ciąg zdarzeń rwie się, ujawniając arytmię. Chwilami Prospero zamiera w bezruchu; , ja to zamrożona burza" - napisze w swoim utworze Heiner Müller, tłumacz Szekspira ${ }^{25}$.

Zrównanie w Burzy czasu fikcji z czasem rzeczywistym spektaklu pociąga za sobą określone konsekwencje: bohaterowie dramatu i widzowie zostają poddani wpływowi tej samej muzyki sfer; i tu i tam akcja rozpoczyna się o trzeciej, kończy o szóstej. Z tą sztuką jest tak, jak zwykle bywa $z$ fugą, choć mówi się o trzyczęściowej budowie, nie znajduje to odbicia w strukturze dzieła, w tym przypadku - pięcioaktowej. Trzy godziny wyznaczają ukryty rytm dramatu. Przez trzy godziny skrawek odkrytego nieba nad głowami widzów elżbietańskiego teatru, zmieniając natężenie i barwę światła, wskazuje na ruch widocznego słońca i ukrytych gwiazd. Ten sam ruch, świadczący przecież o upływie czasu, dostrzegany był także w wydłużających się cieniach aktorów. Słońce wolno wędrujące wewnątrz "drewnianego "O" - jeśliby nie odrywać od niego wzroku - mogło sprawiać wrażenie nieruchomego, zawieszonego poza czasem. W warunkach teatru The Globe zerkanie z rzadka na słoneczną tarczę wydaje się jednak bardziej naturalne, czemu sprzyjać mogły uwagi Prospera precyzujące czas akcji dramatu, jak w akcie I: „A zatem dwie pełne klepsydry. Ten czas, do szóstej wieczorem, musimy wyzy-

${ }^{20}$ R. Koselleck, Kilka problemów z dziejów pojęcia „kryzys”, przeł. M. Łukasiewicz, w: Rozmowy w Castel Gandolfo. O kryzysie, Warszawa 1990, s. 69.

21 Burza, IV, 1, S.B.

22 Tamże, V, 1, S.B.

${ }^{23} \mathrm{~W}$. Rudziński, Wielowarstwowa struktura tempa muzycznego, w: Dzieło muzyczne. Teoria. Historia. Interpretacja, red. I. Poniatowska, Kraków 1984, s. 88.

${ }^{24}$ Burza, IV, 1, S.B.

${ }^{25}$ H. Müller, Opis obrazu, przeł. J.S. Buras, „Dialog” 1985, nr 10, s. 71. 
skać starannie"26 (tłumacz zachował two glasses $\mathrm{z}$ oryginału). W całym teście wspomina się o trzech godzinach, o trzykrotnym odwróceniu klepsydry. Rozstrzygające są tu słowa Bosmana z aktu V:

The best news is that we have safely found

Our king and company: the next, our ship, -

Which but three glasses since we gave out split, -

It tight and yare and bravely rigg'd...

Najlepsza z nowin ta, żeśmy znaleźli

Króla i świtę - następna, że statek,

Któryśmy temu ledwie trzy godziny

Rozbity w drzazgi wszyscy opuścili,

Jest cały, gotów, pięknie wystrojony...27

Możemy sobie wyobrazić, że widz elżbietańskiego teatru, nawykły do określania pory dnia z położenia słońca na niebie, na każde słowo mówiące o upływie czasu reagowal uniesieniem głowy do góry. Oglądać spektakl, odrywając oczy od widowiska i patrząc w niebo, czy nie jest tym samym, co „czytać podnosząc głowę znad książki”? Myśl wybiega wtedy poza tekst - pisze Markowski, komentując Barthesa - „tekst traci nagle swą autonomię i rozprasza się w intertekstualnej mgławicy28". Takich pauz, przecinających tok narracji, jest w Burzy kilka, a częstość ich występowania wydaje się pozostawać $w$ związku $z$ coraz szybszym tempem sztuki. Gdy w akcie I - dosłownie - Prospero raz pyta „Która godzina?”, w akcie II mamy dwa takie przypadki: (1) Sebastian, nawiązując do wypowiedzi Gonzali, mówi do Alonza: „Spójrz, jak nakręca się zegar jego inwencji; zaraz zacznie bić. [...] Licz uderzenia: raz... ${ }^{29}$ oraz (2) Trinkulo, szukając schronienia przed ponownie nadciągającą burzą, woła „Patrzcie na tę czarną chmurę...”30, to w akcie V znajdujemy już cztery spostrzeżenia mówiące o czasie: Prospera, Bosmana i dwa Alonza. Brak pauz rozpraszających koncentrację widzów w aktach III i IV trzeba by tłumaczyć zakończeniami trzech scen, które Szekspir rozegral w konwencji teatru w teatrze: Ariel, jako harpia, przerywa ucztę przygotowaną dla króla Neapolu i jego świty (III, 3), Prospero przerywa „maskę" (IV, 1) oraz Ariel przerywa scenę, w której Trinkulo i Stefano przebierają się w „pstre łaszki” - „przynętę dla złodziei” (IV, 1). Umieszczenie w tej części sztuki słów zachęcających widzów do zadarcia głów w górę mogłoby zakłócić odbiór widowiska, niszcząc teatralną iluzję.

${ }^{26}$ Burza, I, 2, J. Sito.

27 Tamże, V, 1, Z.Siwicka.

${ }_{28}$ M.P. Markowski, Ciało, które czyta, ciało, które pisze, w: R. Barthes, $S / Z$, przeł. M.P. Markowski, M. Gołębiewska, Warszawa 1999, s. 28-29.

${ }^{29}$ Burza, II, 1, S.B.

30 Tamże, II, 2, S.B. 
Kott sądzi, że w Burzy „poprzez kolejne nawroty i powtórzenia przeszłości czas wraca do swego początku”, a klepsydra ,jest obrazem czasu, który powraca"31. Powrót Prospera do Mediolanu miałby sprawić, że również Kaliban i Ariel „wracają do punktu zerowego, od którego zaczęła się fabuła, żeby wszystko raz jeszcze mogło zacząć się od nowa. Przeszłość powróciła na wyspę Prospera"32. Czy chodzi tu jednak rzeczywiście o odwracalność czasu? Prospero nie jest Hiobem, który zawierzył Bogu tak mocno, że Pan Czasów podarował mu nowe życie. Jest to postać raczej bliższa miltonowskim bohaterom, którzy oparcia nie poszukiwali już w Bożym miłosierdziu, lecz we własnych siłach. W epilogu Prospero podkreśli „oto stoję nagi, słabe siły moje, przecie moje" 33 . Jego powrót do rodzinnych stron nie otworzy nowego etapu, lecz zamknie całe życie: "wrócę do Mediolanu, Gdzie śmierć zaprzątnie co trzecią myśl moją"34. Kwestia ta brzmi znacznie bardziej wyraziście w oryginale, gdzie autor stawia znak tożsamości między „Mediolanem” i „grobem”: my Milan my grave. Nadzieje, jakie Prospero wiąże z przyszłością, nie dotyczą jego samego. Oceniając skuteczność zabiegów księcia, Gonzalo nie ma żadnych wątpliwości:

\section{Pan Mediolanu czyżby swój Mediolan \\ Po to utracił, by ród jego objąl \\ Tron Neapolu? ${ }^{35}$}

Zadośćuczynienie za doznane $\mathrm{w}$ przeszłości krzywdy i rzeczywisty powrót może spełnić się jedynie - jak powiada Lévinas - „poza tym, co możliwe”, bo życie córki to dla Prospera „przyszłość poza własnym byciem"36. Tylko przyszłość Mirandy może otworzyć czas Prospera, tylko w dalszym życiu córki mogą spełnić się jego plany. Miranda „nie jawi się jako negacja ojca, lecz jako zmartwychwstanie chwili, na przekór a może i dzięki - śmiercin" ${ }^{37}$, która oddziela dziecko od ojca. Przyszłość dziecka stanowi rodzaj przebaczenia dla chwili poprzedniej - chwili ojca. $\mathrm{O}$ tę chwilę z przyszłości niosącą przebaczenie i o uwolnienie z zamkniętego przez śmierć czasu prosi Prospero w epilogu:

31 J. Kott, Burza albo powtórzenie, w: Szekspir wspótczesny 2, wyb. T. Nyczek, Kraków 1999, s. 205.

32 Tamże, s. 204.

${ }^{33}$ Burza, Epilog, J.S.

${ }^{34}$ Tamże, V, 1, Z.S.

35 Tamże, V, 1, S.B.

36 E. Lévinas, Etyka i nieskończony. Rozmowy $z$ Philippe'em Nemo, przel. B. Opolska-Kokoszka, Kraków 1991, s. 42-43

37 M. Jędraszewski, Wobec innego. Relacje międzypodmiotowe w filozofii Emanuela Lévinasa, Poznań 1990, s. 173. 
Niechaj mnie wasze dobrotliwe ręce

Uwolnią z więzów kres kładąc udręce.

Niechaj wasz oddech w mój żagiel dąć raczy,

Bo się me plany nie spełnią inaczej38.

W Burzy możemy zatem mówić jednocześnie o zachodzących braku ciągłości i ciągłości czasu, ale ciągłość uzyskiwana jest w wolnym wyborze następców wobec swych poprzedników, którzy będą - lub nie będą chcieli budować wspólną podstawę czasu. „Podstawa czasu - jak pisze Deleuze - to Pamięć"39. Jedynie dzięki wytrwałym ćwiczeniom pamięci Czas - zestrojonymi głosami Chóru - może u Szekspira zaświadczyć, że „Luka bynajmniej nie przeczy Temu, że znam dokładnie przeszłość każdej rzeczy"40. Nieciągłość w Burzy jest wyjściowym doświadczeniem czasu. Trudno zgodzić się z Kottem i jego koncepcją powracającego czasu, podobnie jak z odczytaniem symboliki klepsydry, która nie tylko nie jest obrazem powrotu, lecz - przeciwnie - świadczy o luce i zerwaniu: „klepsydrę/Odwrócę - mówi Czas - i z historii szesnaście kart wydrę"41. Właściwości szekspirowskiego czasu nasuwają na myśl późniejszą filozofię Kartezjusza, według której chwila obecna nie może nigdy osiągnąć chwili następnej. Trzykrotne odwrócenie klepsydry - to trzykrotne zerwanie czasu. Trzygodzinny czas Burzy jawi się jako dramat, wielość aktów-godzin, gdzie godzina następna rozwiązuje pierwszą. Przesunięcie słońca o jedną godzinę wprowadzało nieodwracalną zmianę barwy całego nieba i nowy układ gwiazd, ukrytych przed ludzkim wzrokiem. Słońce nad głowami postaci i widzów elżbietańskiego teatru oglądano jak figurę króla w szachach: przesunięcie jej o jedno pole zmieniało układ na całej szachownicy; im dalej od centrum, tym zmiany były radykalniejsze. $\mathrm{Pa}-$ miętano, że słońce to „wódz, król i zwierzchnik pozostałych ciał niebieskich"42.

We współbrzmieniu lub w kontraście z tłem muzyki sfer autor wykreśla linie melodyczne poszczególnych postaci. W polifonicznej strukturze dzieła odkrycie wzajemnych relacji i hierarchii pomiędzy poszczególnymi głosami jest istotnym zadaniem. Sztuka zaczyna się przywołaniem podwładnego przez kapitana tonącego okrętu. Miranda, zachęcona przez ojca do przypomnienia sobie najodleglejszych obrazów z dzieciństwa, również wspomina służących: „Czy nie miałam kiedyś / Czterech czy pię-

${ }^{38}$ Burza, Epilog, Z.S.

${ }^{39}$ G. Deleuze, Różnica i powtórzenie, przeł. B. Banasiak i K. Matuszewski, Warszawa 1997, s. 130.

${ }^{40}$ Zimowa opowieść, IV, 1, S.B.

11 Tamże.

42 Cicero M.T., O państwie, przel. W. Kornatowski, w: Pisma filozoficzne, t. 2, Warszawa 1962, s. 180. 
ciu kobiet na usługi?" Wzbudza to nawet zdziwienie dwudziestowiecznego tłumacza, który ustami Prospera pyta z niedowierzaniem: „Lecz czemu to właśnie / Wyryło ci się w umyśle?"43 Plautowski motyw pana i dwóch niewolników, dobrego i złego, powraca wielokrotnie w Burzy w najróżniejszych przetworzeniach, jak wtedy, gdy w rolę Kalibana wciela się Ferdynand obładowany drewnem na opał. Napięcie, utrzymujące się między wszystkimi obserwowanymi w sztuce podwładnymi i ich przełożonymi, ujawnia już nie tylko komediowy, ale też często tragiczny sens bezwzględnej walki o władzę i sukcesję, w zgodzie lub w sprzeczności z prawem.

Wyjściową trójkę postaci w przekształceniach motywu pana i sługi tworzą: Prospero, Ariel i Kaliban. To relacje między tymi trzema postaciami wyznaczają ramy „realnego” swiata wyspy. Dla pozostałych osób, a więc dla rozbitków ze statku wiozącego wrogów Prospera - ale też i w takim samym stopniu dla Mirandy - wszystko, co się dzieje na tym skrawku lądu, jest teatrem $w$ teatrze przygotowanym siłami magii.

Zastanawia zróżnicowanie postaci: Prospero i Kaliban są ludźmi, Ariel - duchem. Przypomina to technikę trzygłosowego motetu, w którym tylko dwa głosy otrzymywały teksty powierzane śpiewakom. Tekst tenoru miał znaczenie umowne, gdyż głos ten w zasadzie przeznaczony był do wykonania instrumentalnego. Jeśli - jak zakładamy - partie Ariela przypadłyby tenorowi, to jak "przydzielić" pozostałe głosy? Alonzowi imię Prospera kojarzy się „ze strasznymi basowymi rejestrami organów nieba"44, więc załóżmy, że postać maga obdarzono głosem najniższym. Zawężenie skali głosu tak psychologicznie złożonej postaci mogło oznaczać ograniczenie jej możliwości lirycznych i dramatycznych, sprawiając, że rola ta mogłaby stać się nazbyt charakterystyczna. W okresie ars nova nosicielem uczuć był bogaty w melizmaty głos górny. Partię Prospera trzeba by realizować połączonymi siłami: własnego basu i zapożyczonego tenoru. Pozbawiony ciała i oczyszczony w ten sposób z ludzkiej emocjonalności, „instrumentalny” głos Ariela staje się znakomitym medium w przekazywaniu myśli i uczuć pana. Nie do końca jednak Ariel jest przekaźnikiem wyłącznie cudzych emocji, zauważa to Prospero:

Skoro ty, złożony z powietrza tylko, potrafisz wspólczuć,

To ja, $\mathrm{z}$ tej samej ulepiony gliny,

Tymi samymi co oni pasjami

Targany - miałbym pozostać nieczuły?45

${ }^{43}$ Burza, I, 2, S.B.

44 Tamże, III, 3, S.B.

45 Tamże, V, 1, S.B. 
W uchwyceniu zależności między Prosperem i jego sługami pomocna może okazać się alchemiczna symbolika żywiołów, sięgająca antycznych wzorów. Ariel to „powietrze”, w spisie osób dramatu autor pisze: an airy Spirit. Kaliban, nazywany przez Prospera „mułem ziemnym”, „ciężkim zółwiem”, a przez Trynkula - „sprośną rybą”, reprezentuje żywioł ziemi. Prospera, który grozi Arielowi, że w razie nieposłuszeństwa wbije go ,jak klin w sękate trzewia dębu"46, przez nawiązanie do symboliki gromowładnego Jowisza ${ }^{47}$, można identyfikować $\mathrm{z}$ ogniem. Gdy Kaliban, przeklinając Prospera i nazywając go „ślepym kretem"48, życzy mu utraty wzroku, powinniśmy pamiętać o naukach starożytnych, że „bez udziału ognia nic nigdy nie może być widzialne”49. Tylko połączenie „ognia” i „powietrza” jest harmonijne. „Ogień” i „ziemia” pozostają w nieustannym konflikcie, jak Prospero i Kaliban stale na siebie złorzeczący. Związek „powietrza” z „ziemią" to dla Ariela przykra konieczność spełniania „przyziemnych i wstrętnych rozkazów"50.

Żywioły determinują losy postaci. Przewaga Prospera nad Kalibanem, choć utrzymuje się do końca sztuki, wydaje się chwilowa. Prospera ulepiono, jak sam mówi, z gliny i jego ludzkie ciało zbudowane jest

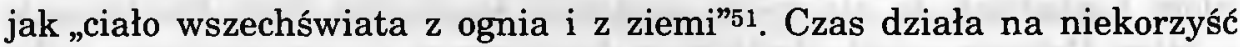
„ognia”, który ziemia w końcu i tak zagłuszy. Dziewiętnastowieczny pisarz Ernest Renan podążający jakby za tą intuicją w swoim dramacie Kaliban, który jest de facto kontynuacją dalszych losów bohaterów $\mathrm{Bu}$ $r z y$, Kalibana osadza na tronie Mediolanu w wyniku „zamachu stanu"52. Bez powietrza ogień nie utrzyma się nazbyt długo; Prospero, uwalniając Ariela, uczyni to wyłącznie w obliczu zbliżającej się śmierci. Rozstanie z Arielem, opóźniane przez Prospera do ostatniej chwili, przypomina opuszczenie ciała przez duszę. Ogień po całkowitym wypaleniu - już jako popiół - zmiesza się w ostatecznej przemianie z ziemią. Dlatego Kaliban - inaczej niż u Kotta ${ }^{53}$, raczej będzie towarzyszył swemu panu do samego końca. Nikt go nie zostawi na rodzinnej wyspie, więc nie wdrapie się „na puste, najwyższe miejsce” opuszczone przez Prospera ${ }^{54}$. „Punkt zerowy”

${ }^{46}$ Tamże, I, 2, S. B.

47 J. Stempowski (ps. P. Hostowiec), Drzewa republiki berneńskiej, „Wiadomości”, nr $48(243)$ z 26.11 .1950 , s. 1.

48 Burza, IV, 1 S.B.

49 Platon, Timaios, w: Dialogi, przeł. W. Witwicki, Warszawa 1993, s. 311.

${ }^{50}$ Burza, I, 2, Z. S.

51 Platon, Timaios, s. 311.

52 J. Ky dryński, Przypisy do Szekspira, Warszawa 1993, s. 20.

53 J. Kott, Burza albo powtórzenie, s. 204.

54 J. Kott, Pateczka Prospera, s. 224. 
Kotta jest tylko mirażem pragnienia domagającego się prostej symetrii, podobnym do gestu pojednania Prospera $z$ schillerowskiej inscenizacji55.

Nic w tekście Burzy nie zapowiada sugerowanego przez Kotta rozwiązania. Gdy Miranda chce odprawić krnąbrnego sługę, ojciec przypomina jej, że "nie możemy się bez niego obejść”, bo „spełnia dziesiątki użytecznych posług"56. Użyteczność Kalibana doceniają również inne postaci dramatu. Egzotyczny wygląd Kalibana wzbudza w Stefano nadzieje łatwego zarobku: "mogę zażądać każdej ceny. Amator na pewno się znajdzie i zapłaci górę pieniędzy"57. Podobnie reaguje Antonio: „To istna ryba, więc znalazłby kupca"58. Gdy to usłyszy Prospero, natychmiast przypomni swoje prawo do własności: „Ten twór mroku należy do mnie”. Chętnych do zabrania Kalibana z wyspy jest zatem wielu. Także ostatnie w sztuce słowa pana i sługi nie zapowiadają ich rozstania:

PROSPERO: [...] Ty idź do chaty - ma być posprzątana, Jeśli chcesz, abym darował ci winy.

KALIBAN: Posprzątam. Będę na przyszłość mądrzejszy ...59

Szekspir intuicyjnie posługiwał się zasadami rządzącymi powtórzeniem i wiedział, że nie może upodobnić losów obu sług. Powtórzenie - pisze Deleuze - jest „działaniem koniecznym i ugruntowanym tylko w stosunku do tego, czego nie można zastąpić. [...] Jeśli wymiana jest kryterium ogólności, to kradzież i dar są kryteriami powtórzenia"60. Ten sam pan jednego sługę obdarowuje, drugiego - grabi. Kaliban jak cień podąży za swym panem do Mediolanu i nigdy nie usłyszy od niego podobnych słów:

My Ariel, chick,

That is thy change: the elements

$B e$ free, and fare thou well!

Mój Arielu,

To już ostatnie zadanie - a potem

Bądź wśród żywiołów wolny i szczęśliwy!

Żegnaj, Arielu! ${ }^{61}$

Dzięki swej bezcielesności Ariel swobodnie wnika w myśli i uczucia Prospera; sługa i pan trwają w stanie pluralistycznego istnienia. Są jed-

55 K. Daniec, Kaprysy Prospera. Szekspirowskie inscenizacje Leona Schillera, Warszawa 1998, s. 143.

${ }^{56}$ Burza, I, 2, S.B.

${ }^{57}$ Tamże, II, 2, S.B.

33 Tamże, V, 1, S.B.

59 Tamże, V, 1, S.B.

${ }^{60} \mathrm{G}$. Deleuze, Różnica i powtórzenie, s. 27.

${ }^{61}$ Burza, V, 1, S.B. 
nak dwa miejsca w Burzy, w których oba te głosy nie nakładają się na siebie, zyskując odrębne i własne brzmienie:

(1) piosenka Ariela $\mathrm{z}$ aktu V. Tam gdzie pszczoła stodycz ssie...62, którą duch śpiewa po otrzymaniu zapewnienia o rychłym zwolnieniu ze służby: „Pośpiesz się duchu! - przyrzeka mu Prospero - Wkrótce będziesz wolny"63;

(2) epilog wygłaszany przez maga, w którym Prospero wyznaje: „Teraz mnie wszystkie czary opuściły”, "Teraz się wyzbywam Zaklętych duchów, z czarów sztuką zrywam"64. Przyjrzyjmy się obu przypadkom.

Pierwszym słowem epilogu jest now, ostatnim - free. Sens wypowiedzi Prospera zawieszony jest między niespodziewanym dla niego odkryciem „paradoksu teraźniejszości” a prośbą o uwolnienie z pętli czasu. Przygotowując plany odzyskania utraconego księstwa, jak też i później precyzyjnie wcielając je w życie, wewnętrznie nie chciał, ale też, zmuszony zewnętrzną sytuacją, nie mógł - bo byłoby to słabością - pozostawiać szczeliny między przeszłością i zaprojektowaną przez siebie przyszłością. Teraz, gdy wszystkie jego plany się ziściły, dostrzegł, że życie w czasie nieustanowionym jest niemożliwe, a to nowe ugruntowanie czasu nie należy już do niego. To od innych, od ich woli i projektów, zależeć będzie jego los, więc stawia dramatyczne pytanie: „Czy tu mam zostać przez was uwięziony, Czy płynąć do Neapolu?"65 Teraz, gdy utracił prawo do przyszłości, uświadamia sobie znaczenie ugruntowania czasu, które, przechodząc od szczytu do fundamentów - pisze Deleuze - „ustala stosunek między gruntem i posiadaczem według tytułu własności". To wewnątrzczasowe ustanowienie ujmuje „czas jako teraźniejszość, która przemija”, dlatego „czas nie wychodzi z teraźniejszości”. Ale teraźniejszość nie przestaje się jednak poruszać i posuwa się „zachodzącymi na siebie susami”66. Ten następny rzut w przyszłość - to kolejne zaplanowanie zdarzeń, które dopiero mają nadejść, należą już jednak do następnego pokolenia. „Teraz" stało się dla Prospera pułapką.

W zwartym tekście epilogu słowo „teraz” powtarza się trzykrotnie, jak w akordzie. Przy drugim now zostaje określony charakter „trójdźwięku" i całego fragmentu: now, 'tis true. Prawda owego „teraz" odnosi się do sytuacji, w której Prospero już „zlamał magiczną laskę”, „księgę utopił w morzu" i z niepokojem oczekuje odpłynięcia statku do Neapolu. Starając się podkreślić wyjątkowość tej sceny w całości spektaklu, jedni reżyserzy kazali aktorowi pozbyć się nie tylko pałeczki i czarodziejskiego

${ }^{62}$ Tamże, V. 1, J.S.

63 Tamże, V. 1, S.B.

64 Tamże, Epilog, Z.S.

65 Tamże, Z.S.

66 G. Deleuze, Różnica i powtórzenie, s. 129-130. 
plaszcza, lecz także peruki ${ }^{67}$, inni, przeciwnie, ubierali go i charakteryzowali na... Szekspira68. Wobec toniki całego dramatu akord $\mathrm{z}$ epilogu pełni funkcję subdominanty. Poznaliśmy położenie akordu neapolitańskiego, gdzie odnajdziemy dominantę?

W piosence Ariela Tam, gdzie pszczoła słodycz ssie...natrafiamy na podobne akordowe zestawienie, nawet wyrazistsze niż we wcześniejszym przykładzie, bo w tym „trójdźwięku” słowa merrily zestawione są bezpośrednio ze sobą:

\section{After Sumer merrily: \\ Merrily, merrily stall I live now \\ Goniąc za latem wesoło, \\ Wesoło żyjąc, wesoło ${ }^{69}$.}

W zapisie nutowym tej piosenki, pochodzącym podobno z czasów Szekspira, przy pierwszym słowie merrily metrum parzyste zmienia się na metrum trójdzielne, taneczne i wesołe ${ }^{70}$. Powtórzenie "wesoło, wesoło, wesoło" nadaje odczuciu teraźniejszości Ariela innego znaczenia niż poznane przez nas w Epilogu. I live now - śpiewa Ariel w upojeniu! Jego „teraz” nie jest znieruchomieniem, „szczeliną, przez którą widać czas"71, jak u Prospera, lecz, przeciwnie, ruchem pełnym życia i szczęściem zdającym się nie znać końca, których nie krępują już więzy zależności sługi wobec pana.

Zlokalizowane przez nas subdominanta $w$ Epilogu i dominanta w pieśni Tam, gdzie słodycz pszczoła ssie...wyznaczają nastroje, które nie należą do ulotnych odczuć postaci, lecz ustanawiają „całość krajobrazu", w jakim przeżywany jest świat dramatu Szekspira. Nastroje te okazują się różnymi sposobami przeżywania czasu. Prospero, to zatroskany o swą córkę, to ogarnięty trwogą bycia „rzuconego ku śmierci” ${ }^{72}$, koncentruje się na jednej, jedynej chwili w jej aktualnej ostrości. Jego czas traci ciągłość, rozpada się na pojedyncze atomy. To, co Prosperowi wydaje się zerwaniem i luką, dla Ariela jest spojeniem i oparciem.

Burza, jak całe ludzkie życie, oscyluje między radością a smutkiem. "Nastroje wzniosłe rozwijają, nastroje przygnębienia wypróbowują zauważa Bollnow - w pierwszych kształtuje się pełnia życia, w drugich trwałość formy”. Analizując "otwierającą siłę" nastrojów uwznioślających, autor Das Wesen der Stimmungen zatrzymuje się przy grossen

${ }^{67}$ J. Kydryński, Przypisy do Szekspira, s. 13.

68 K. Daniec, Kaprysy Prospera, s. 131.

${ }^{69}$ Burza, V, 1, Z.S.

${ }^{70}$ L.C. Elson, Shakesperae in music, Boston 1901, s. 184-186.

$7 \mathrm{H}$. Müller, Opis obrazu, s. 70.

72 M. Heidegger, Bycie $i$ czas, przel. B. Baran, Warszawa 1994, s. 482-483. 
Mittag Nietzschego. Przeżywanie pełni ludzkiej egzystencji ześrodkowujące się $\mathrm{w}$ centralnych punktach dnia, roku i ludzkiego życia (a więc w południu, lecie i młodości) wiąże się $\mathrm{z}$ zanikiem podmiotowości w samozapomnieniu i upojeniu dionizyjskim. Zmienia się charakter czasu, który, bez "wskaźnika kierunkowego "ja”", zostaje pozbawiony celu (Zeit ohne Ziel)73. Ariel jest postacią z "mitycznego snu młodości”, który podobnie jak „lekkoduch Zaratustra” kocha „skoki i uskoki”. Odsłania się w nim nadmiar przyrody jako „prawda, sprzeczność, rozkosz z boleści zrodzona"74. Ariel z równą łatwością buduje i burzy. Kott nazwie go aniołem i katem ${ }^{75}$. To w nim - jak powiedziałby Nietzsche - „dysonans stał się człowiekiem"76.

Nie powinniśmy duchowej natury Ariela traktować z całkowitą dosłownością, na scenie zagrać go może tylko człowiek. $\mathrm{Z}$ tą postacią jest jak z Rozalindą i wieloznacznością jej płci w elżbietańskim teatrze ${ }^{77}$. „Rzecz to niezwykła widzieć kobietę w epilogu - zwraca się Szekspir do widzów po zakończeniu fabuły Jak wam się podoba, mając na myśli tę samą postać - nic w tym przecie nieprzystojnieszego niż widzieć mężczyznę w prologu"78. Mężczyzna grający kobietę i czlowiek - ducha przez caly czas spektaklu (z woli autora, świadomego charakteru sceny, dla której pisał) będą oscylowali na granicy realności i fikcji. Dlatego Ariela nie możemy traktować wyłącznie jako istotę niematerialną. Musimy też dostrzec młodzieńca obsadzonego w tej roli, bowiem autor „postać realną aktora" ujął w swoim dramacie ${ }^{79}$. Gdy aktor w charakteryzacji wzmacniającej efekt starości, lub w wieku zwalniającym z podobnych zabiegów, zapyta jako Prospero „Która godzina?”, usłyszymy dwie odpowiedzi:

ARIEL: Minęło południe.

PROSPERO: Co najmniej trzecia....80

Różnica w ocenie tej samej pory dnia wyznacza początkowy dystans oddzielający Ariela i Prospera. Rzucone od niechcenia słowa „południe”,

73 O.F. Bollnow, Das Wesen der Stimmungen, Freiburg 1941, s. 195-196.

${ }^{74}$ F. Nietzsche, Narodziny tragedii, przel. L. Staff, Kraków 1984 (reprint wcześniejszego wydania), s. 39.

75 J. Kott, Pateczka Prospera, s. 217.

${ }^{76}$ F. Nietz sche, Narodziny tragedii, s. 168.

77 J. Kott, Płeć Rozalindy, Kraków 1992, s. 212.

${ }^{78} \mathrm{Jak}$ wam sie podoba, Epilog, J..U.

79 T. Kubikowski, Siedem bytów teatralnych. O fenomenologii sztuki scenicznej, Warszawa b.r.w., s. 128.

${ }^{80}$ Burza, I, 2, Z. S.; W oryginale rozminięcie się obu postaci w ocenie czasu jest wyrazistsze, choć trudniejsze do uchwycenia w lekturze. Prospero, będąc jakby głuchy na odpowiedź Ariela, godziny odlicza według własnej, wewnętrznej miary. 
„co najmniej trzecia...” - to metryki dwóch osób. Wieloznaczność scenicznego statusu Ariela sprawia jednak, że czas jakby stanął dla niego w miejscu, nie utraci więc ani odrobiny swej młodości. Tymczasem Prospero w ciągu tych samych trzech krytycznych godzin, które dla niego mają wymiar lat, z mężczyzny $\mathrm{w}$ sile wieku przemieni się w starca. W I akcie są jeszcze razem, w V akcie ich drogi się rozejdą. Uwolnienie sługi będzie miało dla Prospera jeszcze jedno znaczenie: definitywnego pożegnania własnej młodości. Zanim to jednak nastąpi, młodość i starość zgodnie współdziałać będą w realizacji planów Prospera. Znajduje to odbicie w strukturze całej sztuki.

Rozgrywane przed oczyma widzów zdarzenia są w Burzy równocześnie szczegółowo opowiadane. W ten sposób każdy, nawet najdrobniejszy motyw, jest podwójnie realizowany w dramatycznej i epickiej formie. Fragmenty narracyjne autor zwykle wplata w dialogi Prospera z Arielem. Opowieści $\mathrm{z}$ wielokrotnie powtarzającymi się zwrotami, wyrażającymi zadowolenie pana $\mathrm{z}$ prac sługi i obietnice szybkiego uwolnienia go, zachęcały niektórych inscenizatorów do „dynamizujących" skreśleń81. Faktycznie mamy tu do czynienia nie $\mathrm{z}$ „kwestiami rozwlekłymi i zbędnymi”, lecz z dwoma, przeciwstawionymi sobie, „stylami muzycznymi". W partiach dramatycznych dominuje "styl" Ariela, wykonawcy projektów przełożonego, w epickich - „styl” Prospera, samodzielnie zapowiadającego mające nastąpić zdarzenia lub, znacznie częściej, wymagającego od sługi uporządkowanego opisania zrealizowanych już zadań.

Przywołajmy odległe analogie ze współczesnej muzyki, sięgając do charakterystyk dzieł Brahmsa i Debussy'ego ${ }^{82}$. Mocna hierarchizacja świadcząca o czasie, "gdzie każde "zdarzenie dźwiękowe" jest ściśle powiązane ze swoim kontekstem” i „gdzie rozwój sprzęga mocno jedne odcinki z drugimi” (Brahms) - wydaje się właściwością stylu Prospera. Natomiast słaba hierarchizacja z czasem, „który nie trwa, w którym zdarzenia zjawiają się w sposób nieprzewidziany, bez związku z kontekstem całości" (Debussy) - bliska jest charakterowi działań Ariela. Podobnie wypada porównanie punktów kulminacyjnych: "gwałtownego, o porywającej mocy” (Prospero w monologach, a zwłaszcza Epilogu) oraz "niepokojącego i nieprzewidywalnego" (Ariel w piosenkach).

Prospero stara się narzucić Arielowi swój sposób działania, pozostawiając mu jednak znaczny margines swobody. W ten sposób w całym przebiegu dramatu obserwujemy przeplatanie się i przenikanie obu stylów. Sykoraks, jak możemy się domyślać, żądała bezwzględnego wyko-

81 K. Daniec, Kaprysy Prospera, s. 130.

${ }^{82}$ R. Francès, M. Imberty, A. Zenatti, Swiat muzyki, przeł. M. Bogdan, H. Kotarska, w: Teksty o Muzyce Współczesnej, „Res Facta Nowa” 3 (12), Poznań 1999, s. 165. 
nywania jej rozkazów, nie pozwalając słudze na własną inwencję, co zakończyło się konfliktem i uwięzieniem ducha. Skuteczna strategia Prospera nie miała na celu wyłącznie realizacji jego własnych interesów, chodziło mu również o wychowanie swego następcy, który godnie zastąpiłby go na wyspie. Gdy uzna, że sługa już do tego dorósł, przekazuje mu władzę: „Dobrze spisałeś się ostatnim razem - Ty i podrzędne duchy [...] Sprowadź całą Czeredę - odtąd będziesz jej przywódcą"83. Ten gest jest nie tylko odwdzięczeniem się pana wobec dobrego sługi, lecz przywraca ład na wyspie, zakłócony jeszcze przez wiedźmę Sykoraks. Na ile jednak edukacja Ariela była trwała a na ile nieznaczącym epizodem? Ariel, jak wynikałoby z jego pieśni, nadal śni „mityczny sen młodości”, podczas gdy Prospero swój edukacyjny program ułożył w kategoriach „historyczno-pragmatycznych dziejów młodości"84. Współpraca starego Prospera i jego młodego sługi wydaje się pojednaniem chwilowym i niepewnym, jak alians Apolla z Dionizosem. Już raz z takiego związku zrodziła się tragedia ${ }^{85}$.

„Typ struktury czasowej” Burzy w szczególny sposób potęguje wrażenie, że sztuka „posiada wszystkie swe części naraz"86. Dzieje się tak w przypadku tego dzieła nie tylko w końcowej refleksji, towarzyszącej zwykle widzowi wychodzącemu już z teatru po zakończonym spektaklu czy czytelnikowi, odkładającemu przeczytaną książkę na półkę, lecz również w trakcie lektury czy przedstawienia. Jest to zjawisko wyjątkowe, na ogół zwracamy bowiem uwagę na "wartość nastrojową", a nie konstrukcję formalną dzieła ${ }^{87}$. Tajemnica niezwykle stabilnej „struktury quasi-czasowej” tego dramatu tkwi w powtórzeniach i w „muzycznej przestrzenności”. Uruchamiając swą wyobraźnię, musimy pamiętać, że przestrzeń tej sztuki może mieć tylko charakter wyobrażony, istotny i wewnętrzny. Zasadniczą cechą tej przestrzeni jest polaryzacja „centrum / peryferie” w tym sensie, jak powiada Tarasti, że „coś w muzyce może być otoczone przez coś innego” lub że „istnieją takie miejsca, które jak gdyby wyróżniają się jak coś "naznaczonego" na tle elementów "nienaznaczonych" 88 . W Burzy jest to Prospero - „aktor-temat" - otoczony innymi częściami lub „instrumentami”, które oplatają się wokół niego.

${ }^{83}$ Burza, IV, 1, S.B.

${ }^{84} \mathrm{~F}$. Nietzsche, Narodziny tragedii, s. 76.

${ }^{85}$ G. Deleuze, Nietzsche i filozofia, przeł. B. Banasiak, Warszawa 1993, s. 16.

${ }^{86} \mathrm{R}$. Ingarden, Utwór muzyczny $i$ sprawa jego tożsamości, Kraków 1973, s. 19.

${ }^{87} \mathrm{Sz}$. Cymernanów na, O działaniu estetycznym muzyki, w: ...A mqdrości zto nie przemoże, red. J. Jadecki, B. Markiewicz, Warszawa 1993, s. 61.

88 E. Tarasti, Przestrzeń muzyczna, przeł. A. Melerowicz, M. Jabloński, w: Teksty o muzyce wspótczesnej, „Res Facta Nova” 1 (10), Poznań 1994, s. 61. 
W muzyce wszystko podporządkowane jest tymczasowości i zasadzie stawania się. Widać to najwyraźniej w zmianach przestrzeni muzycznej, więc prześledźmy w Burzy przesunięcia pierwszego planu i tła, posługując się trzema $\mathrm{z}$ czterech wyróżnionych przez Tarastiego typów dynamiki:

\section{Akty I-V}

1. Przestrzeń zewnętrzna ulega zmianie, wewnętrzna nie.

Ten rodzaj dynamiki Szekspir zastosowal w partiach pisanych „stylem Prospera", akcentując w ten sposób znaczenie głównej postaci z determinacją realizującej swój plan.

2. Równoczesna zmiana przestrzeni zewnętrznej i wewnętrznej.

Zmiany te są charakterystyczne dla fragmentów „zestawionych” w „stylu Ariela”; ujawniają one zależnosć sługi wobec pana.

\section{Epilog}

3. Przestrzeń zewnętrzna pozostaje niezmieniona, podczas gdy wewnętrzna ulega zmianie ${ }^{89}$.

Taką dynamiką autor oddał psychiczne napięcie Prospera w oczekiwaniu efektów zakończonych działań i bolesnym odczuciu niepewności „teraz”.

W zwartej konstrukcji Burzy każde zakłócenie równowagi zwraca uwagę. Tak jest też w przypadku braku prologu. Poszukujących symetrii interpretatorów zmusiło to do nadzwyczajnych działań. Schiller w swojej inscenizacji prolog "wykroił" z monologu Prospera w akcie IV90, a Kott doliczył się dwóch prologów: w opisie statku podczas burzy i rozmowie Prospera $z$ Mirandą $w$ akcie ${ }^{91}$. Wydaje się jednak, że mamy tu do czynienia z paradoksalnym chwytem Szekspira. Co prawda, sztuka zaczyna się od burzy, aby jednak ukazać dynamikę tej sceny, potrzebna jest chwila ciszy. Przysłowiowa cisza przed burzą jest milczeniem żywiołów i milczeniem Prospera. Chodzi zatem o milczenie nagłosowe, a więc rozpoczęcie od milczenia. Niespieszenie się z tekstem, którego się po autorze wszyscy $w$ tym miejscu spodziewają, staje się znaczące - jak pisze Handke o takim przypadku - jest to "milczenie jako tekst”92. Odnalazł się prolog w chwili milczenia, odnalazła się symetria w konstrukcji dramatu, choć z zachowaniem „różnicy ekonomicznej”: niemej scenie prologu odpowiada stretto końcowej przemowy Prospera.

89 Tamże, s. 62.

${ }^{90}$ K. Daniec, Kaprysy Prospera, s. 131.

91 J. Kott, Pateczka Prospera, s.188-189.

${ }_{92} \mathrm{R}$. Handke, Milczenie w perspektywie oczekiwań, w: Semantyka milczenia, red. K. Handke, Warszawa 1999, s. 50-51. 
Wartość tej ciszy była kiedyś nieporównywalnie większa niż we współczesnym teatrze, a to za sprawą stojącego parteru. Zarówno w czasach Szekspira, jak też w teatrach całej Europy do początku XIX w. na stojącym parterze było gwarno i rojno, śmiano się, chodzono, komentowano grę aktorów - parter żył. Wówczas cisza dla dramaturga znaczyła więcej niż oklaski i nawoływania ${ }^{93}$. Dopiero wprowadzenie krzeseł sprawilo, że parter utracił swoją swobodę i ruchliwośćc4. W teatrze elżbietańskim pojawienie się przed rozpoczęciem spektaklu Prospera w bogatym, magicznym płaszczu mogło na chwilę wyciszyć widownię. To nagłe ukazanie się aktora, połączone $\mathrm{z}$ gestem np. odwrócenia klepsydry lub podania tonu na monochordzie, spełniłoby podobną funkcję jak uzgodnienie intonacji i tempa przez współwykonawców archaicznych pieśni w tzw. szeptanym przedtakcie (Flüsterauftakt) ${ }^{95}$. Prospero w ciszy przed burzą jak dyrygent podaje ton czeredzie duchów, oczekujących w skupieniu na rozpoczęcie akcji - taka propozycja wydaje się mieścić w granicach prawdopodobieństwa.

Pokrótce omówiliśmy muzykę wyspy tworzoną przez Ariela. Charakterystykę „muzyki” Kalibana - krnąbrnego sługi Prospera, rozpocznijmy od piosenki z aktu II Żegnaj mi panie... Kaliban w rozbitkach, błaźnie i piwnicznym króla Neapolu odkrył nieznany sobie świat i dostrzegł w nim perspektywy lepszego losu. Poddany pijackiej edukacji swoich nowych panów zdobywa się na odwagę i wypowiada służbę Prosperowi:

Farewell, master; farewell, farewell

Żegnaj mi panie! Żegnaj! Żegnaj!

Głośno wyśpiewuje to, o czym wcześniej szeptał tylko ukradkiem. Trzykrotne „bądź zdrów!” z początku pieśni, jest „akordem” sprzeciwu, dławionym dawniej przez strach. To nie jest zwykły zgrzyt czy dysonans $\mathrm{w}$ bogatej $\mathrm{w}$ dysonanse muzyce wyspy. Kalibanowi chodzi o obalenie dotychczasowego porządku i zerwanie z przeszłością. Jest to więc akord zupełnie nowej muzyki, muzyki nowego człowieka, z którym Kaliban się identyfikuje, bo ma już nowego pana:

Has a new master - Get a new man.

Ma już pana - nowy pan!

93 G. Zapolska, „Otchtañ" - sztuka Konczyńskiego, w: Szkice teatralne, Kraków 1958 , s. 217.

94 K. Estreicher, Parter stojqcy, Kraków 1888, s. 5.

95 J. Stęszewski, Szeptany przedtakt $w$ polskiej muzyce ludowej, w: Dzieto muzyczne. Teoria. Historia. Interpretacja, red. I. Poniatowska, Kraków 1984, s. 98. 
Jest przekonany, że to nowe, "rewolucyjne” brzmienie swej pieśni zawdzięcza przybyszom, więc pewny ich oparcia i siły w ostatnich taktach śpiewa w uniesieniu:

Freedom, high-day! high-day, freedom! freedom! high-day, freedom!

Wolność! Swoboda! Wolność!

Gdy jednak w akcie III Kaliban poprosi Stefana o przypomnienie tamtego podniosłego tonu, okazuje się, że jego nowi mocodawcy nie znają nie tylko nuty, ale i sensu wolności:

KALIBAN: [...] Zanuć piosenkę, którejś mnie nauczył

Przed chwilą.

STEFANO: [...] śpiewa

Zakpijcie $\mathrm{z}$ nich, zadrwijcie $\mathrm{z}$ nich!

Zadrwijcie $\mathrm{z}$ nich, zakpijcie $\mathrm{z}$ nich!

A myśl jest wolna!

KALIBAN: To nie na tę nutę ${ }^{96}$.

Kaliban chciał obalić i zabić Prospera, zaś Stefano i Trynkulo zadowalają się kpiną, dającą tylko pozór działania. W ich ustach cynicznie brzmiące słowa "myśl jest wolna” nie wzywają do czynu. Ten nowy ton, Freedom, high-day! odkrył nieświadomie sam Kaliban. Nie był więc uczniem, mógł za to stać się nauczycielem. Błyskawiczna reakcja Ariela uniemożliwiła taki obrót sprawy. Duch zjawia się z bębenkiem i piszczałką. Dźwięki tych instrumentów, o zmysłowej i drażniącej barwie, wpływały, jak sądzono od starożytności, destrukcyjnie na ludzkie umysły. Były za to bliskie nastrojom obu wesołków: „To jest nuta naszej piosenki grana przez pana Nikogo"97 - zauważy Trinkulo. Gdyby Kaliban, nie korzystając z pomocy Stefano, samodzielnie zanucił pieśń, tak jak ją zapamiętał, a jego kompani podjęliby ten ton, czy losy wyspy potoczyłyby się inaczej?

Zachowania Kalibana nie wydawały się w czasach Szekspira wyjątkowe. Mieszkańcy odległych krain mieli, według rozpowszechnionych wówczas opinii, wykazywać wyraźne skłonności do burzenia zastanego ładu: „Bardzo się im zdawało dziwne - pisano po ich wizycie na jednym z europejskich dworów - aby tylu rosłych, brodatych, silnych i uzbrojonych łudzi, będących dokoła króla”, godziło się poddawać jego woli „i nie wybrało raczej któregoś spośród siebie, aby im rozkazywał"98.

W buntowniczym śpiewie, w środkowej części pieśni, Kaliban wyraża potrzebę wyartykułowania własnego imienia:

96 Burza, III, 3, Z.S.

97 Tamże.

98 M. de Montaigne, Próby, t. 1, przeł. T. Żeleński (Boy), Warszawa 1985, s. 318. 
'Ban, 'Ban, Ca-Caliban,

Ka, Kaliban, ban, ban, ban 99

Niewolnik chce rozpoznać siebie w swoim imieniu. Każdy człowiek „identyfikuje siebie poprzez swe imię", pisze Tischner, „może on drugiemu "oznajmić» swe imię i w ten sposób "przedstawić mu się»"100. Ariel, któremu wolność została podarowana i o którą nie musiał walczyć, w swoim hymnie wyzwolenia, jakim jest pieśń Tam gdzie pszczoła stodycz ssie..., własnego imienia nie umieszcza.

Zatrzymajmy się na imieniu Kalibana, które wielu interpretatorom Szekspira wydaje się echem „kanibali” ze słynnego eseju Montaigne'a101. Dlaczego jednak Prospero miałby posługiwać się zniekształconym brzmieniem słowa? Można by raczej oczekiwać, że wychowywanego niemal od urodzenia sługe nazywałby young cannibal. Gry słowne śpiewającego Kalibana nasuwają hipotetyczne rozwiązanie. Mogło się zdarzyć, że niewolnik jeszcze jako dziecko przysłuchiwał się lekcjom Mirandy, podczas których Prospero czytał jej Montaigne’a - jedną z tych książek, które dostarczył mu Gonzalo w dniu wygnania z Mediolanu. Chłopczyk podchwycił powtarzające się słowo „kaliban”, zniekształcając je dziecinną wymową. Ten żartobliwy zwrot przylgnął już do niego na stałe, stając się imieniem. Po próbie gwałtu na córce Prospera imię „Kaliban” staje się przekleństwem. Mamy tu więc przypadek „poznania przez napiętnowanie, gdzie, jak pisał św. Augustyn, drugi człowiek pojawia się w nim a priori w polu wartości negatywnych ,jako przeciwieństwo tego, kim lub czym powinien być". Prawda człowieka odsłania się przez fałsz człowieka102. „Kaliban” - to imię krzyczy: „jesteś poza swoim miejscem”, „poza swoją prawdą"!

Niewolnik, szukający swojego nowego miejsca i prawdy o sobie, wymawia otrzymane od pana imię w nowym, całkowicie własnym języku. Byłby to przypadek kreacji języka abstrakcyjnego, tak przynajmniej sądzili współcześni, uważając, że Szekspir wynalazł dla Kalibana „odpowiedni i nowy język”"103. Imię „Kaliban” w nowej mowie nabiera tryumfalnego brzmienia. W tym hymnie rozbudzonych nadziei podstawową samogłoską jest „æ”, a spółgłoski są sonantami, o jakości „twardej, pod-

99 Burza, II, 2, Z.S.

$100 \mathrm{~J}$. Tischner, Przestrzeń obcowania $z$ drugim, „Analecta Cracoviensia” 1977, nr 7, s. 72 .

101 N. Frye, Postowie, s. 135.

$102 \mathrm{~J}$. Tischner, Przestrzeń obcowania z drugim, s. 74.

$103 \mathrm{D}$. Norbrook, „What cares these roarers for the name of king?": Language and utopia in "The Tempest", w: The Politics of Tragicomedy. Shakespeare and After, LondonNew York 1992, s. 40. 
kreślając mistyczny ton uniesienia ${ }^{104}$. W najbardziej żywiołowej końcówce pieśni niewolnika, w miejscu spodziewanych „nonsensownych fonemów" znajdujemy powtarzające się dwa słowa: freedom i high-day. Zwłaszcza obecność high-day - „biały dzień” jest szczególnie istotna, bo wskazuje na punkt kulminacji życia Kalibana, podobny do „zenitu sprzyjającej gwiazdy" Prospera. Mając zatem na uwadze trudną do przewidzenia wymowę niewolnika, przyjrzyjmy się walorom asocjacyjnym fonemów zakwalifikowanym wcześniej do „tekstu sztucznego”: Ban i CaCa... Może Ban - to „klątwa” lub „zakaz”, a nie tylko dźwięk imitujący bębny. Natomiast $\mathrm{Ca}$-Ca... - zanim jeszcze słuchający zdąży złożyć poszczególne sylaby w Caliban - może przywołać skojarzenie ze znacznie częściej spotykanym słowem ca'canny - „ostrożnie!” Zestawienie wydobytych z chaotycznego szeregu sylab dwóch znaczeń „zakazu” i „ostrzeżenia” dałoby się odczytać jako „złamanie zakazu”. Mimo płynności zauważonych asocjacji wydaje się, że Kaliban swoją buntowniczą antymowę buduje $z$ elementów języka Prospera i Mirandy. Swiat, który przed nim otworzyli przybysze z Włoch, wydaje mu się znacznie bardziej godny pożądania niż tradycja własnych przodków. To o Mirandzie mówił Kaliban, że „przewyższa urodą Sykoraks Jak szczyt przewyższa dolinę”105. Antymuzyka niewolnika, ugruntowana na sprzeciwie wobec Prospera, faktycznie wyraża zerwanie Kalibana $\mathrm{z}$ jego własną historią, tą bliższą i najodleglejszą.

A może Kaliban nie odcina się od swoich korzeni, lecz sięga po słowa swoich „ciemięzców”, bo nie pozwolono mu zapamiętać własnych. Używając obcych słów, układa je jednak według składni własnej mowy, której melodię utrwalił sobie w dzieciństwie. Słownictwa i gramatyki można się wyuczyć, podczas gdy obcy akcent zdradzi pochodzenie rozmówcy. Warto w tym miejscu zauważyć, że pierwszą reakcją Kalibana na bachiczne śpiewy Stefana w akcie II było przerażenie, sądził, że dręczy go wysłannik Prospera. Muzyka dawnych i nowych przybyszów z Włoch brzmiała dla niego tak samo obco i wrogo. Reakcje w odbiorze muzyki są wynikiem uczenia się i doświadczenia. Szczególna organizacja muzyki rozwinięta w obrębie określonej kultury nie jest uniwersalna, naturalna ani dana przez Boga ${ }^{106}$. Muzyka Kalibana mogłaby być zatem muzyką

104 Do zbliżonych efektów w zakresie zbieżności materiału dźwiękowego z nastrojem pieśni dochodzi w swoich formalnych eksperymentach Joe Bolendas; w Modlitwie dla pokrzepienia serca styszymy podobną do Kalibanowej frazę: „Em e re re re - em e re re re..." - M. Bristiger, Zwiqzki muzyki ze stowem. Z zagadnień analizy muzycznej, Biblioteka Res Facta 4, Kraków 1986, s. 154.

105 Burza, III, 2, S.B.

${ }^{106}$ L.B. Meyer, Emocje $i$ znaczenie $w$ muzyce. przeł. A. Buchner, K. Berger, Biblioteka Res Facta 2, Kraków 1974, s. 16-17. 
rdzennych mieszkańców wyspy i prawowitych właścicieli ziem zagarniętych przez kolonizatorów: „Całą tę wyspę mam w spadku po matce - wypomina niewolnik Prosperowi - Tyś mi ją zabrał"107. Konieczność funkcjonowania Kalibana w ramach narzuconej kultury i trudności z opanowaniem odmiennych zasad czynią go w tym obcym środowisku „niepełnosprawnym”. Spójrzmy na „inność”, a nawet jego „monstrualność” przez pryzmat schematów prześladowczych. Prospero i Miranda - w tym ujęciu - niesprawiedliwie przypisywaliby słudze odpychające cechy i czyny, bo, jak powiada Gerard, „upośledzenie, nawet przypadkowe, niepokoi”, robiąc „wrażenie destabilizacyjnego dynamizmu” i przeraża, bowiem „sugeruje prawdę o systemie, systemie jego względności, kruchości, śmiertelności"108.

Wydaje się, że dobrą ilustracją tak radykalnej rewizji poglądów na świat wartości szekspirowskich postaci jest własna wersja losów Prospera i Kalibana Aimé Césaire'a w dramacie Une tempête ${ }^{109}$. Interesujące są konsekwencje dokonanych zmian. Autor, w podtytule Pour un théâtre négre nawiązując do Murzynów Jeana Geneta, już w spisie postaci ustala nową hierarchię, opartą na kolorze skóry: biały pan (Prospero) i dwaj niewolnicy - mulat (Ariel) i czarny (Kaliban). Otrzymujemy zatem nową historię wyspy zrewidowaną przez jej rdzennych mieszkańców. Césaire obdarza Kalibana świadomością własnej tożsamości: „Nazywaj mnie X. - mówi niewolnik do pana - Tak będzie lepiej. Jakbyś wołał człowieka bez imienia.[...] Za każdym razem, kiedy mnie zawołasz, będziesz przypominał tę podstawową prawdę, że mi wszystko ukradłeś, nawet moją tożsamość!"110. W następstwie tego kroku autor odbiera Prosperowi władzę nad muzyką wyspy. W „masce” balet „bialych”, rzymsko-greckich bogów zostaje przerwany - nie jak u Szekspira przez Prospera - lecz przez miejscowego boga, który zamiast wstrzemięźliwości przedmałżeńskiej głosi pochwałę nieskrępowanej płodności. To muzyka Kalibana, muzyka rdzennej ludności, wypełnia dźwiękami wyspę, to ona ustala obowiązujący ład. Prospero i Kaliban, w stosunku do oryginału, zamieniają się atrybutami: muzyka i mowa Prospera są nieautentyczne, sztuczne i kalekie, Kalibana - naturalne i harmonijne. Une tempête inaczej też się kończy, Prospero, „broniąc zdobyczy białej cywilizacji”, zostaje na wyspie; biali i czarni nie mogą się już rozdzielić. Prospero zwraca się do niewolnika milczącego za ścianą tropikalnego lasu: „Oto, mój stary Kalibanie, zostaliśmy tylko my dwaj na tej wyspie, tylko ty i ja. Ty i ja! Ty-Ja! Ja-Ty!"11.

${ }^{107}$ Burza, II, 2, S.B.

${ }^{108}$ R. Gerard, Kozioł ofiarny, przeł. M. Goszczyńska, Eódź 1982, s. 34.

${ }_{109}$ M. Sugiera, Wariacje szekspirowskie $w$ powojennym dramacie europejskim, Kraków 1997, s. 50.

110 Tamże, s. 52.

111 Tamże, s. 54. 
Prospero zajął miejsce Kalibana. Zamiana ról w niczym nie zmieniła sytuacji: konflikt jest nierozwiązywalny.

Zestawienie Burzy ze zręczną postkolonialną przeróbką Césaire'a ujawnia głębię przesłania pierwowzoru. Szekspira nie interesuje wyłącznie opisanie zbrodniczego mechanizmu władzy, lecz w „układzie eksperymentalnym" wyspy ${ }^{112}$, zasiedlonej przez zredukowaną do absolutnego minimum liczbę osób, poszukuje wyjścia z zaklętego kręgu przemocy. Jak w Księdze Rodzaju dzieje każdej, najdrobniejszej nawet postaci pokazują perspektywę burzliwej historii całych narodów i cywilizacji.

Opozycja między muzyką Kalibana i muzyką Ariela, dobrowolnie podporządkowaną Prosperowi, byłaby de facto zderzeniem o charakterze kulturowym. Dla zakorzenionej w antyku kultury Włoch $\mathrm{i}$ „dionizyjskiej”, ze swego pierwotnego charakteru, kultury Ariela świat symboliki matki Kalibana zdaje się odległy. Sosna Sykoraks była dla nich drzewem z dzikich okolic. W tekstach antycznych, zauważa Stempowski, „nie widzimy wzmianek o drzewach iglastych rosnących koło domów mieszkalnych. Dla Wergiliusza sosna jest piękna tylko w górach. Cień drzew iglastych uchodził za złowróżbny lub szkodliwy dla zdrowia"113. Tak jak Sykoraks w roli władczyni wyspy nie znalazła wspólnego języka z Arielem i jej rządy były pasmem konfliktów, tak też i jej syn, choć tym razem jako sługa, ma podobne trudności, nie potrafiąc porozumieć się z Prosperem. Między muzyką Ariela a muzyką Kalibana jest jakaś szczelina, pęknięcie utrudniające wypracowanie stanu wzajemnej równowagi.

Harmonię, choć nietrwałą, znajdujemy natomiast w relacjach Prospera z Arielem. Tworzony przez Ariela świat dźwięków wyspy wydaje się Prosperowi jakby znany i bliski, tak jak pieśni niektórych ludów z odległych kontynentów kojarzyły się Europejczykom z poezją Anakreonta, a ich język „miękki, o lubym dźwięku” - z kadencjami greckimi ${ }^{114}$. Także Ariel nie miał kłopotów z uchwyceniem właściwego tonu żeglarskich pieśni rozbitków z Włoch. Zgodność Ariela i Prospera można by tłumaczyć zdolnościami ich kultur do przyjmowaniu współpracy z podziałem na role, ze swego rodzaju specjalizacją. „Apollińska” kultura Prospera, przejawiająca się w obrazowych przekazach pośrednich, szukała dopełnienia w „dionizyjskiej” kulturze Ariela, wyrażającej się bezpośrednio, w odtworzeniu, w muzycznym symbolu woli. Obie więc nie przeciwstawiały się sobie jako człony sprzeczności, lecz raczej jako dwa antytetyczne sposoby jej zniesienia. Zróżnicowanie, zapobiegające bezpośredniej rywalizacji i konfrontacjom, pozwalało, mimo odrębnych historii i doświadczen, odnajdywać wzajemne podobieństwa i wytworzyć na jakiś czas nową wspól-

112 H. Müller, Opis obrazu, s. 70.

${ }_{113} \mathrm{~J}$. Stem powski (ps. P. Hostowiec), Drzewa republiki berneńskiej, s. 1.

114 M. de Montaigne, Próby, t. 1, s. 318. 
notę. Muzyki Prospera i Ariela, zachowując swój styl, indywidualną różnorodność i bogactwo, znalazły jedność we wspólnym źródle: muzyce sfer. Czy niezdolność Kalibana w nawiązywaniu dialogu z innymi wynikała $\mathrm{z}$ charakteru jego buntowniczej antymuzyki? Czy też przyczyna ukryta była głębiej, w przeszłości, w jakimś „grzechu pierworodnym” jego przodków?

Szekspir kończy sztukę wygaszeniem burzliwych namiętności. Nawet Kaliban wycisza się, jakby pokornieje. Trwałe to rozwiązanie czy tylko pozorne? Pytanie o jedną muzykę, o dwie czy o więcej muzyk jest faktycznie pytaniem o charakter samego sporu, który może prowadzić do samounicestwienia lub - przeciwnie - stanie się, jak powiada Heidegger, „harmonijnością przynależenia do siebie spierających się stron”. Czy rysa, którą dostrzegliśmy w budowie Burzy jest rozdarciem w sensie pękającej szczeliny? A może jest takim odgraniczeniem, które nie dzieli, lecz łączy, nie pozwalając "rozpaść się przeciwzwrotnym stronom, lecz prowadzi je do miary i granicy w zgodny obrys" 115 .

115 M. Heidegger, Źródto dzieła sztuki, przeł. J. Mizera, w: Drogi lasu, Warszawa 1997, s. 44. 